Teologia i Moralność, volumen 12(2017), numer 2(22)

doi: 10.14746/tim.2017.22.2.6

\author{
ZBIGNIEW ZAREMBSKI \\ Uniwersytet Mikołaja Kopernika w Toruniu \\ Wydział Teologiczny
}

\title{
Pastoralne wsparcie małżeństwa i rodziny w poszanowaniu życia
}

Zagadnienie życia i rzeczywistość rodziny ściśle się ze sobą łączą i można powiedzieć, że są niemalże nierozdzielne. Wystarczy chociażby zajrzeć do dokumentów Soboru Watykańskiego II, a w nich do Konstytucji duszpasterskiej o Kościele Gaudium et spes i przyjrzeć się uważnie soborowej definicji małżeństwa. Dokument mówi bardzo wyraźnie, że małżeństwo i rodzina to „głęboka wspólnota życia i miłości małżeńskiej” (KDK 48). Również u św. Jana Pawła II w encyklice Evangelium vitae znajdujemy niezwykle jasne określenie rodziny, które wyraża jakże głęboką prawdę o rodzinie i jej związku z darem życia. Papież pisze bowiem, że: „Rodzina jest powołana, aby spełnić swoje zadanie w ciągu całego życia swoich członków od narodzin do śmierci. Jest prawdziwym sanktuarium życia [...] miejscem, w którym życie dar Boga, może w sposób właściwy być przyjęte i chronione przed licznymi atakami, na które jest ono wystawione, może też rozwijać się zgodnie z wymogami prawdziwego ludzkiego wzrostu. Dlatego rodzina odgrywa decydującą i niezastąpioną rolę w kształtowaniu kultury życia" (EV 92) ${ }^{1}$.

Wyrażenie „sanktuarium” oznacza w Kościele katolickim przestrzeń uznaną za miejsce święte, przestrzeń, w której w sposób szczególny Bóg udziela swojej łaski. Ów termin używany jest obecnie w teologii moralnej na określenie sumienia. Zapożyczony został z dokumentu soborowego, który w ten sposób określił sumienie: ,jest ono bowiem najtajniejszym ośrodkiem i sanktuarium człowieka, gdzie przebywa on sam z Bogiem" (KDK 16) ${ }^{2}$. Po raz kolejny odnajdujemy to określenie użyte $\mathrm{w}$ stosunku do rodziny w nauczaniu

\footnotetext{
${ }^{1}$ Zob. W. Bołoz, Promocja osoby w rodzinie, Warszawa 1998, s. 107-115.

${ }^{2}$ Zob. Z. Wanat, Sumienie w blasku prawdy, Toruń 2012.
} 
papieża Jana Pawła II. Rodzina jest „miejscem świętym”, ponieważ życie ludzkie otoczone jest w niej szacunkiem (EV 92). Tak być powinno, jednakże ze względu na współczesny kryzys, jaki dotyka chrześcijańskie rodziny - nie jest to oczywiste. Nie wszystkie rodziny darzą życie szacunkiem, a te, które to czynią, z pewnością potrzebują wsparcia ze strony różnych instytucji i podmiotów, szczególnie zaś od Kościoła.

Niniejsza publikacja poświęcona jest pastoralnemu wsparciu małżeństw i rodzin w poszanowaniu życia. Składa się ona z czterech części, w których autor kolejno prezentuje wartość i nienaruszalność ludzkiego życia, opisuje podstawowe środowisko ludzkiego życia, czyli rodzinę, której misją jest przekazywanie i ochrona życia. W dalszej kolejności znajdujemy omówienie misji Kościoła, który powołany jest do tego, aby służyć człowiekowi i rodzinie, a jego szczególnym zadaniem jest wspieranie rodziny w dziele afirmacji życia. Zwieńczeniem artykułu jest prezentacja wybranych form i sposobów pastoralnego wsparcia rodziny, do których zaliczone zostało słowo Boże, świadectwo życia małżonków, towarzyszenie małżonkom i rodzinie oraz konkretne działania podejmowane przez Kościół w obronie życia.

\section{Wartość i nienaruszalność ludzkiego życia}

Kościół naucza, że życie ludzkie od poczęcia do naturalnej śmierci jest największą wartością, gdyż jest ono święte i nienaruszalne (EV 53) ${ }^{3}$. Objawienie Boże poucza o wielkiej jego wartości, stwierdzając, że jest ono darem pochodzącym od Boga. W dziele stworzenia świata powołanie do istnienia człowieka jako mężczyzny i kobiety ukazane zostało jako ukoronowanie całego dzieła stworzenia (Rdz 1,26-27). Człowiek stał się istotą żywą przez tchnienie życia, otrzymane od Stwórcy (Rdz 2,7). Życie ofiarowane człowiekowi jest zatem darem, dzięki któremu Bóg udziela „coś” z siebie stworzeniu.

W wydarzeniu tym chodzi o całą sferę duchową, dzięki której życie człowieka jest czymś więcej niż tylko istnieniem w czasie, ale jest dążeniem ku pełni życia, zalążkiem istnienia, które przekracza granice czasu. Człowiek żyje więc jako istota cielesno-duchowa, nosząc w sobie obraz i podobieństwo Boga $(\operatorname{Rdz} 1,26)$. To sprawia, że wyróżnia się on spośród innych istot żyjących na ziemi, względem których jest panem i władcą. Nie jest jednak absolutnym panem wobec własnego życia. Właściwe posługiwanie się darem życia doczesnego umożliwia człowiekowi spełnienie powierzonych mu przez Boga zadań, a w ostateczności wpływa na jego stan w życiu wiecznym.

${ }^{3}$ Zob. J. Nagórny, Wartość życia ludzkiego, red. K. Jeżyna, J. Gocko, W. Rzepa, Lublin 2009, s. $15-112$. 
Każdej osobie ludzkiej przysługuje prawo do życia. Na straży tego prawa stoi przykazanie Boże, które zabrania pozbawiać życia samego siebie, a także odbierać je innym. Człowiek ma w sobie życie, które chronione jest przez piąte przykazanie dekalogu, mówiące - nie zabijaj. Stwierdzić jednak należy, że jego trwaniu przeszkadza śmierć, która pojawiła się na Ziemi w następstwie grzechu pierworodnego. Bóg jednak nie ma upodobania w śmierci $(E z$ 18,32) i dlatego zesłał Syna swego, aby człowiekowi przywrócić życie ${ }^{4}$.

Godność życia nie wynika tylko z jego źródła, czyli z faktu, że pochodzi ono od Boga, ale także z celu, jakim jest przeznaczenie do komunii z Bogiem. Kościół w swoim nauczaniu ujmuje wartość życia w kategoriach świętości. W chrześcijańskiej koncepcji życia funkcjonuje przekonanie, że życie cielesne dla każdego wierzącego stanowi niepowtarzalne i wielkie dobro, bez którego nie można mówić o jego wymiarze wiecznym. Życie doczesne jest drogą i przygotowaniem ku egzystencji utożsamianej z byciem „twarzą w twarz” z Bogiem.

Z prawdy o świętości życia wynika zasada jego nienaruszalności, która $z$ jednej strony zakazuje niszczenia życia, a z drugiej nakazuje jego bezwzględne poszanowanie, troskę o nie i ochronę. $\mathrm{Za}$ przekazywanie życia ludzkiego odpowiedzialność ponoszą rodzice, będący współpracownikami Boga-Stwórcy. W związku z tym, że Bóg stwarza nieśmiertelną duszę dziecka, poczęte życie nie jest wyłącznie dziełem rodziców ani ich własnością. Rodzice nie mogą więc o nim samowolnie decydować6. Według św. papieża Jana Pawła II rodzina jest ,sanktuarium życia”. Tylko właściwy małżeństwu „wzajemny dar z samego siebie, mężczyzny i kobiety, stwarza takie środowisko życia, w którym dziecko może się urodzić i rozwijać swe możliwości, nabywać świadomość własnej godności i przygotować się do podjęcia swego jedynego i niepowtarzalnego przeznaczenia" (CA 39).

Odczytanie pełnej wartości życia ludzkiego wiąże się również bardzo mocno z przekonaniem, że życie ludzkie ma charakter osobowy, a więc różni się w sposób istotny od życia innych ziemskich stworzeń. Jednak we współczesnym świecie zauważa się, że człowiek pojmowany jest jako jedna z wielu istot żyjących, że jest jedynie organizmem, który osiągnął wysoki stopień

${ }^{4}$ Episkopat Polski, Biskupi wzywaja do obrony poczętego życia ludzkiego na uroczystość Świętej Rodziny 1975 (12 II 1975), w: Listy Pasterskie Episkopatu Polski 1945-2000, cz. 1, Marki 2003, s. 1027; zob. E. Ozorowski, Życie, w: Slownik malżeństwa i rodziny, red. tenże, Warszawa-Łomianki 1999, s. 505-506.

${ }^{5}$ H. Skorowski, Życie, w: Encyklopedia bioetyki. Personalizm chrześcijański. Gtos Kościoła, red. A. Muszala, Radom 2005, s. 526-528; Zob. M. Machinek, Życie w dyspozycji człowieka. Wybrane problemy etyczne u poczatku ludzkiego życia, Olsztyn, 2004; tenże, Śmierć w dyspozycji człowieka. Wybrane problemy etyczne u kresu ludzkiego życia, Olsztyn 2004.

${ }^{6}$ Episkopat Polski, Biskupi wzywaja do obrony poczętego życia ludzkiego na uroczystość Świętej Rodziny 1975 (12 II 1975), w: Listy Pasterskie Episkopatu Polski 1945-2000, cz. 1, s. 1027. 
rozwoju. Taki pogląd sprawia, że zostaje on potraktowany jako swoista rzecz, a tym samym gubi się jego wymiar transcendentny. Sam człowiek przestaje traktować swoje życie jako wspaniały dar Boży, a zaczyna postrzegać je jako rzecz, w związku z czym uważa, że można je traktować jako swoją wyłączną własność (EV 1; 2).

Święty Jan Paweł II zwracał uwagę wiernych Kościoła na konieczność integralnego odczytywania wartości życia ludzkiego, zarówno z perspektywy naturalnej (stwórczej), jak i w świetle całego dzieła zbawczego. Należy zaznaczyć, że podobnie jak cała antropologia chrześcijańska ukierunkowana jest na Chrystusa, tak też pełne odczytanie wartości ludzkiego życia jest możliwe tylko w odniesieniu do Niego. Chrystus powiedział „Ja przyszedłem po to, aby owce miały życie i miały je w obfitości” (J 10,10).

\section{Rodzina - wspólnotą życia}

Rodzina to podstawowe środowisko życia, w którym człowiek przychodzi na świat, gdzie wzrasta, dojrzewa, przygotowując się do życiowych zadań. Słusznie zatem powiedziano, że człowiek to istota rodzinna-homo familiaris, gdyż w gruncie rzeczy to od rodziny i jej kondycji zależy pomyślność świata i Kościoła. Św. Jan Paweł II napisał w adhortacji Familiaris consortio, że „rodzina stanowi jedno z najcenniejszych dóbr ludzkości” (FC 1) oraz że „przyszłość świata idzie przez rodzinę" (FC 86), jednak koniecznie dopowiedzieć trzeba, że nie od każdej, lecz od rodziny silnej i trwałej, przepełnionej głębokimi wartościami i będącej „Kościołem domowym”. Tylko taka rodzina daje to wszystko, co jest niezbędne w stawaniu się coraz bardziej człowiekiem ${ }^{7}$.

Pochylenie się nad rodziną sprawia, że w pamięci przywołuje człowiek dom rodzinny, dzieciństwo, bliskie osoby, rodziców czy też rodzeństwo. I w ten sposób uświadamia sobie niezwykłą wartość i siłę, jakie kryją się we wspólnocie rodzinnej, oraz jak wiele jej zawdzięcza. Okazuje się niepodważalną prawdą, że to właśnie miłość rodzicielska i troskliwa opieka najbliższych stanowią fundament pełnego rozwoju człowieka, który w najgłębszej istocie nie jest samotną wyspą, lecz przeciwnie jest istotą społeczną. Doświadczenie i wnikliwa obserwacja pokazują, że w świecie istot żywych nikt tak nie potrzebuje pomocy, miłości i troski najbliższych, jak właśnie istota ludzka. To zapotrzebowanie na ,innych”, na osoby znaczące, stanowi niezaprzeczalny dowód na niekwestionowaną rolę rodziny w ludzkim życiu.

${ }^{7}$ Z. Zarembski, Rodzina naturalnym środowiskiem wychowania w nauczaniu Jana Pawła II, „Studia Włocławskie”, t. 3, 2000, s. 334-344; tenże, W służbie rodziny, w: Ocalić dziedzictwo. Świętemu Janowi Pawłowi II w X rocznicę nadania doktoratu honoris causa Uniwersytetu Mikołaja Kopernika w Toruniu, red. J. Bagrowicz, W. Karaszewski, Toruń 2015, s. 239-253. 
Rodzina to środowisko, od którego zależy to, kim będziemy. W zrozumieniu wartości rodziny pomaga objawienie i prawdy zawarte w Piśmie Świętym, gdyż odsłaniają one zamysł Boży względem niej. Wpisana jest w dzieło stworzenia i odkupienia. Jest również wpisana w tajemnicę Kościoła, będąc na mocy sakramentu małżeństwa „Kościołem domowym”. Według nauczania Jana Pawła II pełni ona cztery fundamentalne zadania: tworzenie wspólnoty osób; służbę życiu - przekazywanie życia i wychowanie; uczestnictwo w rozwoju społeczeństwa i uczestnictwo w życiu i misji Kościoła (FC 17-64).

Święty Jan Paweł II stwierdził, że ochrona i promocja życia jest zadaniem wpisanym w powołanie małżeńsko-rodzinne (EV 92). „Rodzina jest powołana, aby spełnić swoje zadanie w ciągu całego życia swoich członków od narodzin do śmierci. Jest prawdziwym sanktuarium życia" (EV 92). Szczególną rolę odgrywają w niej małżonkowie, gdyż to oni wezwani są po to, aby być przekazicielami życia „na podstawie nieustannie odnawianej świadomości sensu rodzicielstwa, pojmowanego jako doniosłe wydarzenie, że życie ludzkie jest darem, który przyjmuje po to, aby ponownie go ofiarować" (EV 92). Owocem wzajemnego daru miłości rodziców jest ich dziecko. To ono mówi rodzicom o celu ich życia, reprezentuje ono ich miłość i pozwala myśleć o przyszłości. Jan Paweł II podkreślił, że rodzice stają się głosicielami Ewangelii życia przede wszystkim poprzez wychowanie dzieci, które należy rozumieć jako duchowe rodzenie ${ }^{8}$.

Przez słowo i przykład, przez codzienne kontakty i decyzje, przez konkretne gesty i znaki rodzice uczą swoje dzieci autentycznej wolności, która się urzeczywistnia przez bezinteresowny dar z siebie i rozwijają w nich szacunek dla innych, poczucie sprawiedliwości, postawę serdecznej akceptacji innych, dialogu, wielkodusznej służby i solidarności oraz wszelkie inne wartości, które pomagają przyjmować życie jako dar. Praca wychowawcza chrześcijańskich rodziców powinna służyć rozwojowi wiary dzieci i pomagać im w spełnianiu powołania, które otrzymały od Boga (EV 92).

Istotnym środkiem afirmacji życia $\mathrm{w}$ rodzinie jest codzienna modlitwa osobista i rodzinna, w której wychwala się Boga i dziękuje Mu za dar życia, prosząc o światło i moc, aby stawiać czoło trudnościom i cierpieniom ${ }^{9}$. Niezwykle ważna jest przy tym ludzka solidarność okazywana sobie przez drobne i skromne gesty, a także konkretne działania. Papież Jan Paweł II dostrzegł wyjątkowe znaczenie adopcji oraz wzięcie pod opiekę dzieci porzuconych przez rodziców czy też żyjących w trudnych warunkach. Prawdziwa miłość

${ }^{8}$ Zob. Z. Zarembski, W stużbie rodziny, dz. cyt., s. 249.

9 Zob. Z. Zarembski, Modlitwa w życiu rodziny w świetle adhortacji „Familiaris consortio”, „Ateneum Kapłańskie” 148 (2007), z. 588, s. 267-277. 
ojcowska i macierzyńska przejawia się w przyjęciu dzieci pochodzących z innych rodzin i obdarzaniu ich tym wszystkim, co jest ,im potrzebne do życia i pełnego rozwoju" (EV 93). Wśród form adopcji wymienia także adopcję na odległość, pozwalającą zapewnić rodzicom niezbędną pomoc, aby mogli utrzymać i wychować własne dzieci. Solidarność powinna urzeczywistniać się również poprzez różne formy udziału w życiu społecznym i politycznym. Rodziny zaangażowane $\mathrm{w}$ odpowiednie organizacje oddziałują bowiem na prawodawstwo i na instytucje państwowe, aby te nie naruszały prawa do życia od poczęcia do naturalnej śmierci, ale z determinacją chroniły je i umacniały.

Wszyscy członkowie rodzin mają spełniać misję głoszenia Ewangelii życia, ponieważ są wezwani do daru z siebie w miłości. Autorytet, stałość i życie w związkach rodzinnych stanowią podstawy bezpieczeństwa i braterstwa w społeczeństwie. Rodzina jest wspólnotą, w której od dzieciństwa można nauczyć się wartości moralnych, czcić Boga i dobrze używać wolności. Przekazywać je mogą również osoby starsze, które nie tylko powinny być przedmiotem troski, opieki i służby, lecz mogą wnosić pozytywny wkład w Ewangelię życia. Ważne jest więc, aby wykorzystać ich bogate doświadczenie, jakie zdobyły w ciągu całego swojego życia. Nauczanie kościelne potępia spychanie ludzi starszych na margines bądź ich odrzucanie ${ }^{10}$.

Mówiąc o szacunku wobec życia, nie można pominąć rodzin, które zamknięte są na dar życia, uciekają przed prokreacją, stosując antykoncepcję, a niekiedy i aborcję. W życiu tych rodzin górę bierze nie dobro istoty ludzkiej lecz wygodny styl życia, zamknięcie na dziecko, na dar życia. Zagrożeniem dla ludzkiego życia są również często: niewłaściwie wykorzystywane badania nad ludzkimi embrionami, techniki sztucznej prokreacji, niż demograficzny, konsumpcjonizm, hedonizm, relatywizm moralny, alternatywne związki, a także związki jednopłciowe.

\section{Misja Kościoła w służbie rodziny i życiu}

Celem działalności pastoralnej Kościoła na rzecz małżeństwa i rodziny jest okazywanie pomocy małżeństwu i rodzinie w odkrywaniu i przeżywaniu powołania oraz posłannictwa (FC 69). Troska Kościoła wpisana jest w działania duszpasterstwa zwyczajnego i nadzwyczajnego, szczególnie jednak specjalnego, do którego należy duszpasterstwo rodzin. Wyraża się ona w licznie podejmowanych działaniach, które obejmują dużą liczbę szczegółów, ponieważ takim bogactwem charakteryzuje się rodzina. Stąd duszpasterskie działania powinny być na teologicznych podstawach, aby nie doszło do zagubienia się,

\footnotetext{
${ }^{10}$ Zob. Jan Paweł II, List do osób w podeszłym wieku (1 X 1999), Poznań 1999.
} 
rozbicia i rozczłonkowania na poszczególne akcje, do zdominowania całości jakimś jednym punktem widzenia: prawnym, psychologicznym czy socjologicznym. Aby duszpasterstwo było adekwatne do rzeczywistości, powinno odpowiadać również na znaki czasu i wczuwać się w nowe zjawiska i potrzeby tak indywidualnych małżeństw i rodzin, jak i całych grup. Unikać musi wszelkiej jednostronności działań, gdyż to oznaczać może płyciznę i nieskuteczność oddziaływania $^{11}$.

Posługa zbawcza Kościoła na rzecz rodziny (zarówno w ramach duszpasterstwa zwyczajnego jak i nadzwyczajnego) powinna przebiegać na trzech płaszczyznach i obejmować działalność nauczycielską, liturgiczną i pasterską. W centrum działalności pastoralnej Kościoła winna zawsze być rodzina. Tak nauczał bł. Paweł VI w encyklice Humane vitae, uznając duszpasterstwo rodzin za jedną z najważniejszych dziedzin duszpasterskiej posługi Kościoła, a także św. Jan Paweł II, nauczając o duszpasterstwie rodzin jako pierwszoplanowej dziedzinie działalności Kościoła (FC 65). W tym duchu nauczał również Benedykt XVI i obecny papież Franciszek, sytuując małżeństwo i rodzinę w centrum posługi pastoralnej Kościoła.

Niewątpliwie ważną rolę $\mathrm{w}$ uświadomieniu sobie przez rodziny, że są „sanktuarium życia”, odgrywa duszpasterstwo rodzin. Dlatego ze swej strony Kościół winien rozwijać tę działalność zbawczą, aby pobudzić każdą rodzinę do odkrycia i przeżywania z radością i odwagą misji wyznaczonej jej przez „Ewangelię życia”"12.

\section{Formy i sposoby wsparcia rodziny w poszanowaniu życia}

Chociaż prawdą jest, że „przyszłość ludzkości idzie przez rodzinę”, trzeba przyznać, że w dzisiejszych warunkach społecznych, ekonomicznych i kulturowych zadania rodziny w służbie życia stają się często trudniejsze i bardziej uciążliwe. „Aby rodzina mogła wypełnić swoje powołanie jako sanktuarium życia i komórka społeczeństwa, które miłuje i przyjmuje życie, należy koniecznie i pilnie zapewnić jej pomoc i oparcie" (EV 94).

W umacnianiu rodziny i udzielaniu jej pomocy, w odkrywaniu tożsamości fundamentalną rolę odgrywa słowo Boże i zawarta w nim prawda o małżeń-

11 J. Wilk, Duszpasterstwo rodzin: zasady praktycznego działania, „Homo Dei” 68 (1998), nr 4, s. 43-44. B. Mierzwiński, J. Wilk, R. Bieleń, Duszpasterstwo rodzin, w: Teologia pastoralna, red. R. Kamiński, t. 2, Lublin 2002, s. 414-415.

${ }^{12}$ E. Janiak, Rodzina jako ,, sanktuarium życia”, w: Życie - dar nienaruszalny. Wokót encykliki „Evangelium vitae”, red. A. Młotek, T. Reroń, Wrocław 1995, s. 76-78; K. Majdański, Życie w blasku prawdy, w: „Evangelium vitae” - ocaleniem rodziny, red. K. Majdański, S. Stefanek, Częstochowa 1997, s. 120; A. Skreczko, J. Zabielski, Życie jako zobowiązujący dar, Białystok 2011. 
stwie i rodzinie. Rodzina według Bożego słowa to wspólnota, komunia osób mężczyzny i kobiety oraz dzieci, będąca obrazem jedności między Ojcem, Synem i Duchem Święty (AL 29). „Przed rodzinami i pośród nich zawsze powinno rozbrzmiewać pierwsze orędzie, które jest tym, co jest najpiękniejsze, większe, bardziej pociągające i jednocześnie bardziej potrzebne" (AL 58) i ono też „powinno zajmować centralne miejsce w działalności ewangelizacyjnej” (EG 164). Do tego orędzia trzeba stale powracać, słuchać go oraz głosić je na różne sposoby, zwłaszcza podczas katechezy (EG 164). Nie ma tak naprawdę nic bardziej pewnego i treściwego od przepowiadania, dlatego cała formacja chrześcijańska ma być głoszeniem kerygmy (EG 165, zob. AL 58), a w sercu każdej rodziny trzeba postawić kerygmat, aby oświetlał on drogę życia małżeńsko-rodzinnego. „Wszyscy powinniśmy móc powiedzieć, na podstawie tego co przeżywamy w rodzinie: Uznaliśmy miłość jaka Bóg ma względem nas $(1 \mathrm{~J} \mathrm{4,16)}$. To dopiero wychodząc od tego doświadczenia duszpasterstwo rodzin będzie mogło umożliwić rodzinom bycie Kościołem domowym i jednocześnie zaczynem ewangelizacji w społeczeństwie" (AL 290) ${ }^{13}$.

Papież Franciszek zauważa, że „konieczne jest, aby nie ograniczać się do czysto teoretycznego głoszenia oderwanego od rzeczywistych ludzkich problemów. Duszpasterstwo rodzin musi wiedzieć z doświadczenia, że Ewangelia rodziny jest odpowiedzią na najgłębsze oczekiwania osoby ludzkiej" (AL 201). Stąd też nie można ograniczyć się tylko do czysto teoretycznego głoszenia, lecz ma ono dotyczyć spraw życia codziennego.

W obliczu przeżywania zwątpienia, słabości, zamknięcia na dar życia czy zagubienia małżeństwo i rodzina chrześcijańska mają kierować swój wzrok w stronę świętej Rodziny z Nazaretu i od niej czerpać duchowe bogactwo. Przymierze miłości i wierności, którym żyła Święta Rodzina z Nazaretu, rzuca bowiem światło na zasadę, która nadaje kształt każdej rodzinie i pozwala jej lepiej radzić sobie ze zmiennymi kolejami życia i historii. Na tym fundamencie wspólnota rodzinna, także w swojej słabości, może „stać się światłem w mroku świata" (AL 66). W nauczaniu obecnego papieża bardzo mocno zaznaczona jest troska o rozwój duchowości i modlitwy rodzinnej. Wszyscy domownicy powinni być dla siebie współpracownikami łaski i świadkami wiary (AL 321). Zrozumienie tajemnicy rodziny chrześcijańskiej możliwe staje się W „świetle nieskończonej miłości Ojca, która objawiła się w Chrystusie" (AL 59).

Zadaniem Kościoła jest zawsze docieranie do rodzin z pokornym zrozumieniem i chęcią ,towarzyszenia każdej i wszystkim rodzinom, aby odkryły najlepszy sposób przezwyciężenia trudności napotkanych na swojej drodze"

${ }^{13}$ Zob. Z. Zarembski, Wskazania papieża Franciszka dla duszpasterstwa rodzin, w: Duszpasterstwo w świetle nauczaniu papieża Franciszka, red. D. Lipiec, Lublin 2014, s. 163-180. 
(AL 200). Kościół i duszpasterstwo rodzin ma towarzyszyć rodzinom, organizować zwłaszcza poradnictwo, aby w ten sposób pomagać w umacnianiu relacji rodzinnych, rozwoju miłości, przezwyciężaniu konfliktów i wychowaniu dzieci. Towarzyszenie to ma obejmować całe życie rodzinne, a szczególnie ma być odczuwalne w pierwszych latach. Przede wszystkim chodzi tutaj o uzupełnienie procesu, który został zainicjowany i dokonał się w okresie narzeczeństwa, gdyż „małżeństwa nie można pojmować jako czegoś zakończonego”, a wzajemne wypowiedziane „tak” to dopiero początek „wspólnej drogi, której cel może przewyższać to, co mogą narzucać okoliczności i mogące pojawić się przeszkody" (AL 218). Papież Franciszek w swoim nauczaniu podkreśla potrzebę umacniania miłości młodych małżonków (AL 220), jak również zachęca ich do „gotowości do prokreacji w przeciwieństwie do mentalności, która jest często wroga życiu" (AL 222). Zachęta ta odgrywa istotną rolę w odkrywaniu tożsamości powołania małżeńskiego.

W procesie umacniania rodziny ważną rolę odgrywać ma parafia, wspólnoty i ruchy kościelne a także sami małżonkowie, których ,świadectwo jest najbardziej czytelnym sposobem ukazywania wartości i piękna powołania małżeńsko-rodzinnego" (AL 223-226). Duchowieństwo ma zatem pomóc małżonkom w zrozumieniu podstawowej prawdy o wartości małżeństwa i życia. Ma uświadomić im, że sakrament małżeństwa to nie jest jakiś „moment, który staje się częścią przeszłości i wspomnień, ale wywiera on swój wpływ na całe życie małżeńskie w sposób trwały" (AL 215). Parafie, ruchy, szkoły i inne instytucje Kościoła powinny organizować: spotkania małżeństw z sąsiedztwa czy zaprzyjaźnionych, krótkie rekolekcje dla małżonków, konferencje specjalistów, dotyczące bardzo konkretnych problemów związanych z życiem rodzinnym, prokreacją, prowadzić warsztaty formacyjne dla rodziców dzieci problemowych oraz tworzyć ośrodki poradnictwa małżeńskiego.

Wyrazem troski Kościoła o promocję i obronę życie są podejmowane liczne działania, pośród których wskazać należy na modlitewne, realizowane w ramach Krucjaty Modlitwy w Obronie Poczętych Dzieci i Duchową Adopcję. Istotną rolę odgrywają nabożeństwa i modlitwy w intencji życia organizowane w świątyniach zwłaszcza w święto Zwiastowania Pańskiego, które jest równocześnie Świętem Życia.

Ważnym zadaniem w praktyce pastoralnej jest działalność edukacyjna, zmierzająca do pogłębienia wiedzy na temat życia dziecka w łonie matki. Wymienić w tym miejscu należy zaangażowanie Zespołów Synodalnych lub Akcji Katolickiej. Inną formą edukacji są także organizowane wystawy, poświęcone życiu dziecka w okresie prenatalnym oraz skutkom aborcji.

Obronie życia służą organizowane marsze życia i powstałe liczne Domy Samotnej Matki, Katolickie Ośrodki Adopcyjno-Opiekuńcze i Okna Życia. Jednak istotne miejsce w obronie życia należy przypisać sprawnie działają- 
cemu poradnictwu rodzinnemu. Wśród szerokiego zakresu zadań stojących przed poradniami rodzinnymi należy wyodrębnić trzy dziedziny: wychowanie dzieci i młodzieży do miłości poprzez regularne spotkania z nimi ,a także z ich rodzicami; przygotowanie narzeczonych do małżeństwa oraz pomoc małżonkom i rodzinom przeżywającym jakiekolwiek trudności, zwłaszcza pomoc w zakresie odpowiedzialnego rodzicielstwa. Nauczanie Kościoła podkreśla bardzo mocno specyficzną i ważną rolę poradnictwa rodzinnego w zakresie posługi życia (EV 88). W obliczu skomplikowanej sytuacji, w jakiej znajdowały się małżeństwa i rodziny, a także młodzi ludzie przed małżeństwem, nie wystarcza jedna centralna poradnia $\mathrm{w}$ diecezji. Zgodnie $\mathrm{z}$ zarządzeniami episkopatu Polski powinno się dążyć do stworzenia sieci parafialnych poradni życia rodzinnego. Spektrum zadań spoczywających na poradnictwie jest bardzo szerokie i obejmuje różnorakie działania skierowane na małżeństwo i rodzinę. Dyrektorium duszpasterstwa rodzin zasadniczy cel poradnictwa określa jako organizowanie pomocy rodzinom w odpowiednio szerokim zakresie. Jako pierwsze zadanie wymienia się ukazywanie właściwego wymiaru miłości małżeńskiej i rodzinnej, w tym czystości przedmałżeńskiej i małżeńskiej. Na drugim miejscu znajduje się uwrażliwienie na godność każdego człowieka od chwili poczęcia aż do naturalnej śmierci. Wśród innych zadań dokument wymienia kształtowanie postaw prorodzinnych, ukazywanie potrzeby pełnego miłości towarzyszenia dziecku od poczęcia, a także niesienie pomocy w rozwiązywaniu konfliktów rodzinnych i problemów wychowawczych. Wśród wymienionych bardzo istotnych zadań na miejscu czwartym znalazło się zadanie nauczania zasad odpowiedzialnego rodzicielstwa, w tym metod diagnostycznych rozpoznawania okresów płodności małżeńskiej, by w ten sposób pomóc małżonkom w rozwoju dwu istotnych wymiarów miłości małżeńskiej: jedności i płodności (DDR 39) ${ }^{14}$.

Znawca problematyki małżeńskiej ks. prof. Bronisław Mierzwiński w jednej ze swoich publikacji zauważa, że bardzo często zarówno duszpasterze, jak i wierni nie doceniają znaczenia i roli poradni życia rodzinnego ${ }^{15}$. Działalność poradni zazwyczaj sprowadza się do przygotowania narzeczonych do małżeństwa, a pomija się całe spektrum świadczonych usług. Także spowiednicy nie doceniają w pełni usług, jakie poradnictwo rodzinne może

${ }^{14}$ Zob. Pierwsza Instrukcja Episkopatu Polski dla duchowieństwa o przygotowaniu wiernych do sakramentu malżeństwa i o duszpasterstwie rodzin, w: J. Buxakowski, Wprowadzenie do teologii duszpasterstwa rodzin, Pelplin 1999, s. 366-379; II Instrukcja Episkopatu Polski dotyczaca przygotowania do malżeństwa i życia rodzinnego oraz wprowadzenia nowego obrzędu sakramentu malżeństwa (11 III 1975), w: Dokumenty duszpastersko-liturgiczne Episkopatu Polski 1966-1993, oprac. C. Krakowiak, L. Adamowicz, Lublin 1994.

${ }^{15}$ Zob. B. Mierzwiński, Stużba życiu w strukturach diecezjalno-parafialnych, w: „Evangelium vitae”-ocaleniem rodziny, red. K. Majdański, S. Stefanek, Częstochowa 1997, s. 152-153. 
oddać małżonkom. Tymczasem już Pierwsza Instrukcja Episkopatu Polski dla duchowieństwa o przygotowaniu wiernych do sakramentu malżeństwa $i$ o duszpasterstwie rodzin zobowiązywała wszystkich spowiedników „by penitentów nie zorientowanych w moralnych sposobach planowania rodziny skierowali w razie potrzeby do najłatwiej dostępnego katolickiego poradnictwa rodzinnego, stawiając to jako wymaganie konieczne do owocnego korzystania z sakramentów" ${ }^{16}$. Udział poradnictwa w służbie życia jest nieoceniony, i to zarówno na etapie przygotowania do małżeństwa, w trakcie jego trwania, a także w okresie starości. Niewątpliwie od samego początku powstania poradnictwa spoczywało na nim zadanie przygotowania małżonków do odpowiedzialnego podjęcia rodzicielskiej służby. Nauczanie Konferencji Episkopatu Polski zalecało więc, aby „ludzie dobrej woli mogli się nauczyć kierowania rodzicielską płodnością zgodnie z prawem Bożym i z wymaganiami zdrowotnymi”, korzystając z pomocy pracowników przyparafialnych poradni rodzinnych ${ }^{17}$. Obecnie obok edukacji w zakresie naturalnych metod regulacji poczęć coraz częściej należy udzielać porad w zakresie możliwości wdrażania nowych metod diagnozowania i leczenia niepłodności, jak chociażby naprotechnologii ${ }^{18}$.

W obronę życia zaangażowane są bardzo mocno stowarzyszenia i ruchy religijne, których powstaniu przyświecał cel pogłębienia świadomości społecznej w zakresie promocji i ochrony życia. Obecnie istnieje prawie 130 ruchów broniących życia i rodziny. Prawie wszystkie są zrzeszone w Polskiej Federacji Ruchów Obrońców Życia, która została powołana w czerwcu 1992 roku z inicjatywy prof. Alicji Grześkowiak. Podstawowym zadaniem Polskiej Federacji Ruchów Obrońców Życia stało się inspirowanie i popieranie wszelkich działań zmierzających do ukształtowania systemu prawnego w Polsce, który chroniłby życie i zdrowie matki i jej dziecka od momentu poczęcia. W ramach Federacji powołano do istnienia Fundację „Głos dla Życia”, wydającą o takiej samej nazwie miesięcznik obrońców życia (DDR 80). Edukacji

16 Pierwsza Instrukcja Episkopatu Polski dla duchowieństwa o przygotowaniu wiernych do sakramentu malżeństwa i o duszpasterstwie rodzin, w: J. Buxakowski, Wprowadzenie do teologii duszpasterstwa rodzin, III, 1.

${ }^{17}$ Episkopat Polski, Biskupi Polscy wzywaja do niesienia pomocy zagrożonej rodzinie (31 X 1972), w: Listy Pasterskie Episkopatu Polski 1945-2000, cz. 1, s. 913; Episkopat Polski, List Biskupów Polskich na uroczystość Świętej Rodziny (11 XII 1980), w: Listy Pasterskie Episkopatu Polski 1945-2000, cz. 2, Marki 2003, s. 1309; D. Kwapisz, Osiagnięcia poradnictwa rodzinnego, w: Troska Kościoła o rodzine w Polsce, red. T. Kukołowicz, Warszawa 1992, s. 90-95; W.B. Skrzydlewski, Planowanie rodziny - wyzwanie moralne, Kraków 1998, s. 157-168; M. Wieczorek, Naturalne planowanie rodziny w polu działania Duszpasterstwa Rodzin, w: Naturalne planowanie rodziny w ujęciu wybranych dyscyplin naukowych, red. W. Wieczorek, E. Flader, R. Krupa, J. Płońska, A. Zaremba, Lublin 2008, s. 438.

${ }^{18}$ Zob. E. Wiater, Naprotechnology. Ekologia płodności, Kraków 2009, s. 5-6. 
i promocji życia ludzkiego służyły również w nieoceniony sposób prasa, radio i telewizja katolicka ${ }^{19}$.

W związku z faktem, że życie ludzkie jest zagrożone również w ostatniej fazie, czyli w starości, a przy tym bardzo często brakuje zrozumienia dla sensu chrześcijańskiego cierpienia, nauczanie Kościoła jednoznacznie opowiada się przeciwko eutanazji. Przejawem troski o ludzi chorych i umierających było i jest poparcie dla idei hospicyjnej

Reasumując prezentację różnych form eklezjalnego wsparcia rodziny w poszanowaniu ludzkiego życia, trzeba raz jeszcze zwrócić się w stronę samej rodziny i jej zaangażowania w sprawę obrony życia. Świadectwo życia samych rodzin to niewątpliwie bardzo ważna forma przekształcania mentalności przeciwnej życiu i wpisuje się ona doskonale w pastoralne działania Kościoła, gdyż rodzina jest „Kościołem domowym”, a małżonkowie mają coraz bardziej stawać się aktywnym podmiotem duszpasterstwa życia i rodzin (AL 200).

Świadectwo dawane przez samych małżonków i rodziny w procesie wychowania do szacunku wobec życia odgrywa rolę fundamentalną, to bowiem małżonkowie są tymi, którzy są dawcami życia i jego opiekunami. Według papieża Franciszka ich świadectwo ,jest najbardziej czytelnym sposobem ukazywania wartości i piękna powołania małżeńsko-rodzinnego" (AL 223-226). Od rodziny bowiem wszystko zależy, gdyż to ona daje fundamenty na całe życie. W rodzinie przecież dziecko uczy się odpowiedzialności, szacunku dla drugiego człowieka i przygotowuje się do założenia własnej rodziny. Cennym udziałem rodziny w promocję życia jest jej aktywne zaangażowanie w szeroko rozumiane duszpasterstwo rodzin a zwłaszcza w inicjatywy podejmowane na rzecz życia. Wyjątkowe znaczenie powinna mieć posługa w poradni rodzinnej i zaangażowanie małżonków w przekazywanie wiedzy na temat odpowiedzialnego rodzicielstwa; ważnym obszarem ich działalności jest także udział w przygotowaniu bliższym młodych do małżeństwa, zaangażowanie w pedagogizację innych rodzin, jak również w prowadzenie konferencji i katechez rodzinnych.

${ }^{19}$ Episkopat Polski, List pasterski o miłości matżeńskiej oraz o prawie do życia wszystkich dzieci poczętych. Radość życia (21 XI 1991), w: Listy Pasterskie Episkopatu Polski 1945-2000, cz. 2, s. 1760; J. Michalik, Episkopat Polski, List pasterski metropolity przemyskiego „Obrony życia poczętego domaga się uczciwość ludzka i wiara" (18 VIII 1996), w: http://jmichalik.episkopat. pl/dokumenty/3160.1,Obrony_zycia_poczetego_domaga_sie_uczciwosc_ludzka_i_wiara.html (23 III 2013); zob. A. Skreczko, Troska Kościoła katolickiego w Polsce o rodzine po drugiej wojnie światowej, „Rocznik Teologii Katolickiej” UwB 2(2003), s. 41-73; J. Kamiński, Zadania duszpasterstwa rodzin, „Roczniki Pastoralno-Katechetyczne” 4(2012), s. 81-92; A. Kwiatkowska, Czasopisma katolickie o pomocy rodzinie samotnej matki, w: Troska Kościoła o rodzine w Polsce, red. A. Kwiatkowska, s. 159-166; P. Wosicki, Organizacje i ruchy społeczne działajace na rzecz dziecka poczętego i jego rodziny, w: Komisja Episkopatu Polski Duszpasterstwa Ogólnego, Program duszpasterski na rok 1993/94, Ewangelizacja wspólnoty malżeńskiej i rodzinnej, Katowice 1993, s. 205-208; W. Śmigiel, Zrzeszenia rodzin katolickich w Polsce, „Roczniki Pastoralno-Katechetyczne" 57(2010), z. 6, s. 72-74. 


\section{PASTORAL SUPPORT FOR MARRIAGE AND THE FAMILY IN RESPECT FOR LIFE}

\section{Summary}

The problem of life and the reality of the family are closely connected and one can safely say that they are almost inseparable. It is enough to look at the documents of the Second Vatican Council to see that marriage and the family are a deep union of married life and love (Gaudium et Spes 48). St. John Paul II in the encyclical Evangelium Vitae highlights the relationship between the family and the gift of life (EV 92).

This publication is dedicated to the pastoral support of marriages and families in respect for life. It consists of several parts in which the author presents successively the value and inviolability of human life, describing the basic environment of human life, that is a family whose mission is the transmission and protection of life. Next, we find a discussion of the mission of the Church, which is called to serve man and family and especially to support the family in the affirmation of life. The article culminates in the presentation of selected forms and ways of pastoral support for the family, including the word of God, the witness of the spouses' lives, accompanying spouses and family, and concrete actions the Church undertakes to defend life.

Słowa kluczowe: życie; małżeństwo i rodzino; pastoralne wsparcie; świadectwo; towarzyszenie; obrona życia

Keywords: life; marriage and family; pastoral support; witness; accompaniment; defense of life

\section{BIBLIOGRAFIA}

Bołoz W., Promocja osoby w rodzinie, Warszawa 1998.

Episkopat Polski, Biskup Polscy wzywaja do niesienia pomocy zagrożonej rodzinie (31 X 1972), w: Listy Pasterskie Episkopatu Polski 1945-2000, cz. 1, Marki 2003, s. 909-914.

Episkopat Polski, Biskupi wzywaja do obrony poczętego życia ludzkiego na uroczystość Świętej Rodziny 1975 (12 II 1975), w: Listy Pasterskie Episkopatu Polski 1945-2000, cz. 1, Marki 2003, s. 1025-1029.

Episkopat Polski, List Biskupów Polskich na uroczystość Świętej Rodziny (11 XII 1980), w: Listy Pasterskie Episkopatu Polski 1945-2000, cz. 2, Marki 2003, s. 1307-1310.

Episkopat Polski, List pasterski o miłości malżeńskiej oraz o prawie do życia wszystkich dzieci poczętych. Radość życia (21 XI 1991), w: Listy Pasterskie Episkopatu Polski 1945-2000, cz. 2, Marki 2003, s. 1744-1763.

II Instrukcja Episkopatu Polski dotyczaca przygotowania do malżeństwa i życia rodzinnego oraz wprowadzenia nowego obrzędu sakramentu małżeństwa (11 III 1975), w: Dokumenty duszpastersko-liturgiczne Episkopatu Polski 1966-1993, oprac. C. Krakowiak, L, Adamowicz, Lublin 1994, s. 239-245.

Jan Paweł II, List do osób w podeszłym wieku (1 X 1999), Poznań 1999. 
Janiak E., Rodzina jako „,sanktuarium życia”, w: Życie - dar nienaruszalny. Wokół encykliki „Evangelium vitae", red. A. Młotek, T. Reron, Wrocław 1995, s. 76-78.

Kamiński J., Zadania duszpasterstwa rodzin, „Roczniki Pastoralno-Katechetyczne” 4(2012), s. 81$-92$.

Kwapisz D., Osiagnięcia poradnictwa rodzinnego, w: Troska Kościoła o rodzinę w Polsce, red. T. Kukołowicz, Warszawa 1992, s. 90-95.

Kwiatkowska A., Czasopisma katolickie o pomocy rodzinie samotnej matki, w: Troska Kościoła o rodzinę w Polsce, red. A. Kwiatkowska, Warszawa 1992, s. 159-176.

Machinek M., Śmierć w dyspozycji człowieka. Wybrane problemy etyczne u kresu ludzkiego życia, Olsztyn 2004.

Machinek M., Życie w dyspozycji człowieka. Wybrane problemy etyczne u poczatku ludzkiego życia, Olsztyn, 2004.

Majdański K., Życie w blasku prawdy, w: „Evangelium vitae” - ocaleniem rodziny, red. K. Majdański, S. Stefanek, Częstochowa 1997, s. 112-122.

Michalik J., Episkopat Polski, List pasterski metropolity przemyskiego „Obrony życia poczętego domaga się uczciwość ludzka i wiara" (18 VIII 1990), w: http://jmichalik.episkopat.pl/doku menty/3160.1,Obrony_zycia_poczetego_domaga_sie_uczciwosc_ludzka_i_wiara.html [dostęp: 23.03.2013].

Mierzwiński B., Stużba życiu w strukturach diecezjalno-parafialnych, w: „Evangelium vitae” - ocalenim rodziny, red. K. Majdański, S. Stefanek, Częstochowa 1997, s. 145-155.

Mierzwiński B., Wilk J., Bieleń R., Duszpasterstwo rodzin, w: Teologia pastoralna, red. R. Kamiński, t. 2, Lublin 2002, s. 403-442.

Nagórny J., Wartość życia ludzkiego, red. K. Jeżyna, J. Gocko, W. Rzepa, Lublin 2009.

Pierwsza Instrukcja Episkopatu Polski dla duchowieństwa o przygotowaniu wiernych do sakramentu matżeństwa i o duszpasterstwie rodzin, w: J. Buxakowski, Wprowadzenie do teologii duszpasterstwa rodzin, Pelplin 1999, s. 366-379.

Skreczko A., Troska Kościoła katolickiego w Polsce o rodzinę po drugiej wojnie światowej, „Rocznik Teologii Katolickiej” UwB 2(2003), s. 41-73.

Skreczko A., Zabielski J., Życie jako zobowiazujący dar, Białystok 2011.

Skrzydlewski W.B., Planowanie rodziny - wyzwanie moralne, Kraków 1998.

Śmigiel W., Zrzeszenia rodzin katolickich w Polsce, „Roczniki Pastoralno-Katechetyczne” 57(2010), z. 6, s. 65-75.

Wanat Z., Sumienie w blasku prawdy, Torun 2012.

Wiater E., Naprotechnology. Ekologia płodności, Kraków 2009.

Wilk J., Duszpasterstwo rodzin: zasady praktycznego działania, „Homo Dei” 68 (1998), nr 4, s. 43-56 .

Zarembski Z., Modlitwa w życiu rodziny w świetle adhortacji „Familiaris consortio”, „Ateneum Kapłańskie" 148 (2007), z. 588, s. 267-277.

Zarembski Z., Rodzina naturalnym środowiskiem wychowania w nauczaniu Jana Pawła II, „Studia Włocławskie", t. 3, Włocławek 2000, s. 334-344.

Zarembski Z., W stużbie rodziny, w: Ocalić dziedzictwo. Świętemu Janowi Pawłowi II w X rocznice nadania doktoratu honoris causa Uniwersytetu Mikołaja Kopernika w Toruniu, red. J. Bagrowicz, W. Karaszewski, Wydawnictwo Naukowe UMK, Toruń 2015, s. 239-253.

Zarembski Z., Wskazania papieża Franciszka dla duszpasterstwa rodzin, w: Duszpasterstwo w świetle nauczaniu papieża Franciszka, red. D. Lipiec, KUL Lublin 2014, s. 163-180.

ZBigNiEW ZAREMBSKI - kapłan diecezji włocławskiej; doktor habilitowany nauk teologicznych - specjalność teologia pastoralna; profesor nadzwyczajny w Katedrze Teologii Praktycznej na Wydziale Teologicznym Uniwersytetu Mi- 
kołaja Kopernika w Toruniu; proboszcz parafii Chrystusa Króla we Włocławku (2007-2012); prodziekan ds. nauki (2008-2012), prodziekan ds. dydaktycznych i studenckich (2012-2016) WT UMK; współredaktor czasopisma teologicznego „Ateneum Kapłańskie” (Włocławek); redaktor tematyczny działu „Familia” w czasopiśmie akademickim „Teologia i Człowiek” (Toruń); członek Rady Naukowej serii Teologia Pastoralna w Polsce Polskiego Stowarzyszenia Pastoralistów; członek Toruńskiego Towarzystwa Naukowego w Toruniu; w 2016 roku wybrany do zarządu Polskiego Stowarzyszenia Pastoralistów Polskich. W swoim dorobku ma trzy książki i kilkadziesiąt artykułów z zakresu teologii pastoralnej i familiologii. 